\title{
BEBERAPA SEGI KEMUKJIZATAN ALQURAN
}

\author{
Moh. Arsyad Ba'asyien
}

STAIN Datokarama Palu, Jl. Diponegoro 23 Palu e-mail: m.arsyad.baasyien@yahoo.co.id

\section{Abstract}

The i'jâz of the Qur'an, which scholars define as the idea that the Qur'an constitutes something exceeding the customary, associated with challenge (tahaddî) and yet free from opposition, has received much attention from classical times to the modern era. Scholars have tried to determine what aspects of the Qur'an constitute i'jâz. Some of them have argued that language structure is an aspect of its i'jâz; some have pointed out that another aspect of $i^{\prime} j a \hat{z} z$ is the information provided about concealed events, including the stories about previous prophets and information about future events. Nevertheless, for the purpose of this article, the writer will discuss three aspects of i'jâz of the Qur'an only.

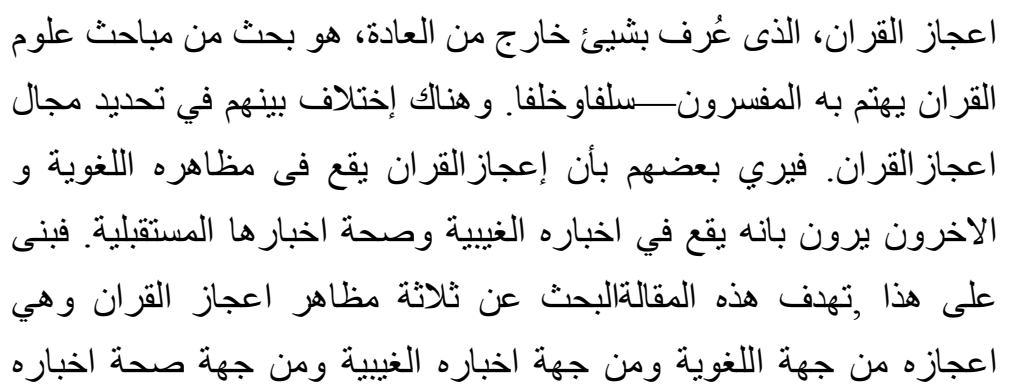

Kata Kunci: i'jâz, kemukjizatan Alquran, mukjizat kebahasaan, mukjizat peristiwa masa lampau 


\section{PENDAHULUAN}

Alquran yang diyakini oleh umat Islam sebagai firman Allah, harus dapat membuktikan diri sebagai wahyu dari Allah, bukan buatan Nabi Muhammad, sebagaimana yang dituduhkan oleh orang-orang kafir Qurays. Hanya dengan kekuatannya sendiri, Alquran akan mampu mengatasi dan mengalahkan orang-orang yang akan menandinginya, bahkan akan mampu mempertahankan keasliannya sepanjang zaman.

Pembuktian ini sangat penting agar manusia yang meyakini kebenaran Alquran, akan semakin mantap imannya dan tidak meragukan sedikit pun kebenaran Alquran. Bagi yang meragukan kebenaran Alquran, tentu akan berusaha menantangnya dengan berbagai cara dan usaha. Namun demikian, dengan kemukjizatan Alquran, usaha apapun yang dilakukan oleh orang-orang yang meragukan kebenarannya, akan berakhir dengan kegagalan.

Apabila dikatakan bahwa Alquran memiliki kemukjizatan, atau Alquran itu sendiri adalah mukjizat, tentu tidak dapat diterima begitu saja sebelum diteliti dan dikaji kemukjizatannya. Sebagai kitab suci, pernyataan-pernyataan Alquran sangat menakjubkan karena pernyataan-pernyataannya ada yang di luar jangkauan pikiran manusia.

Alquran sebagai pegangan hidup umat Islam, tidak berlaku untuk satu zaman tertentu saja, melainkan berlaku untuk sepanjang zaman. Inilah antara lain kemukjizatan Alquran yang selalu dapat dipertahankan keasliannya dan kesuaiannya dengan perkembangan zaman. Oleh karena itu, jika tidak mampu menunjukkan kemukjizatannya, pada akhirnya Alquran akan ditinggalkan oleh penganutnya.

Para ilmuan Islam, baik ilmuan klasik maupun ilmuan Islam modern, telah banyak berbicara tentang kemukjizatan Alquran. Di antara mereka, ada berbicara kemukjizatan Alquran dari segi kebahasaan, seperti gaya bahasa dan uslub Alquran, segi pemberitaan gaib Alquran dan tentang peristiwa yang diungkap oleh Alquran, akan terjadi pada masa akan datang.

Tanpa bermaksud mengabaikan berbagai segi kemukjizatan Alquran yang begitu bervariasi, sesuai dengan ruang yang tersedia bagi tulisan ini, penulis hanya mengkaji tiga di antaranya, yaitu 
kemukjizatan Alquran dari segi kebahasaan, dari segi kebenaran peristiwa yang akan terjadi di masa datang.

\section{PENGERTIAN I'JAZ ALQURAN}

Kata i'jâz adalah bentuk masdar dari kata kerja a'jaza-yu'jizui'jâz yang berarti menjadikan seseorang atau sesuatu lemah dan tidak berdaya. Untuk menjadikan manusia lemah, Alquran adalah mu'jiz atau mu'jizah. Penambahan al-tâ' al-marbûtah pada kata mu'jizah sebagai maksud mubâlagah atau penekanan walaupun dalam Alquran sendiri, tidak ditemukan ayat yang menyatakan bahwa Alquran adalah $m u$ 'jiz. Alquran adalah âyah, burhân dan sultân. Unsur-unsur ini merupakan bagian dari pengertian i'jâz Alquran, karena i'jâz Alquran adalah tanda, dan bukti dari prediksi bahwa manusia tak dapat menirunya (Makhluf, 1978:17-18).

Al-Himsî (1952:340) berpendapat bahwa pengertian i’jâz mengalami perkembangan sebagai akibat dari persentuhan kaum muslimin dengan penganut agama lain yang menuntut perdebatan terbuka tentang hakekat Alquran dan kenabian Muhammad.

Secara etimologis, dalam Kamus Besar Bahasa Indonesia ,mukjizat diartikan sebagai kejadian (peristiwa) ajaib yang sukar dijangkau oleh kemampuan akal manusia (Depdikbud, 1994:670). Sementara itu, mukjizat didefinisikan oleh pakar agama Islam, antara lain, sebagai suatu hal atau peristiwa luar biasa yang terjadi melalui seorang yang mengaku nabi, sebagai bukti kenabiannya yang ditangtangkan kepada yang ragu, untuk melakukan atau mendatangkan hal yang serupa, namun mereka tidak mampu melayani tantangan itu (Shihab, 1997:23).

Berdasarkan kedua pengertian di atas, terdapat perbedaan antara pengertian mukjizat yang kita temukan dalam Kamus Besar Bahasa Indonesia dengan pengertian mukjizat yang dikemukakan oleh pakar agama Islam. Perbedaan itu terletak pada (1) kejadian yang ajaib tersebut terjadi atau dipaparkan oleh orang yang mengaku nabi; (2) mengandung tantangan terhadap yang meragukan kenabian;dan (3) tantangan tersebut tidak mampu atau gagal dilayani (Shihab, 1997: 2324). 
Untuk tujuan penulisan artikel ini, penulis cenderung sependapat dengan definisi yang diajukan oleh pakar agama Islam.

\section{KEMUKJIZATAN DARI SEGI KEBAHASAAN}

Setiap nabi yang diutus, senantiasa disesuaikan dengan keahlian masyarakatnya. Menurut Shihab (1997:111), hal ini karena suatu keistimewaan baru dapat menjadi bukti bila aspek yang dikemukakan dapat dimengerti oleh mereka yang ditantang; dan bahwa bukti tersebut, akan semakin membungkamkan bila aspek tantangan dimaksud menyangkut sesuatu yang dinilai sebagai keunggulan yang ditantang.

Sangat populer kita ketahui bahwa Alquran diturunkan dalam bahasa Arab karena masyarakat yang kepadanya pertama kali Alquran menggunakan bahasa Arab dalam berkomunikasi. Walaupun demikian, Alquran secara tegas menyatakan bahwa Alquran bukan semata-mata untuk orang-orang Arab, melainkan untuk seluruh alam.

Alquran pertama kali berinteraksi dengan masyarakat Arab pada masa Nabi Muhammad. Keahlian mereka adalah bahasa Arab dan sastra Arab. Di mana-mana terjadi musabakah (perlombaan) dalam menyusun syair atau khutbah, petuah, dan nasihat. Syair-syair yang dinilai indah, digantung di ka'bah, sebagai penghormatan kepada penggubahnya sekaligus untuk dinikmati oleh yang melihat atau membacanya. Penyair mendapat kedudukan yang istimewa dalam masyarakat Arab. Mereka dinilai sebagai pembela kaumnya. Dengan syair dan gubahan mereka reputasi suatu kaum atau seseorang dan juga—sebaliknya—dapat menjatuhkannya (Shihab,1972:111-112).

Karena alasan inilah, Alquran memiliki gaya bahasa yang khas yang tidak dapat ditiru oleh para sastrawan Arab, karena susunannya yang indah yang berlainan dengan setiap susunan dalam bahasa Arab. Mereka menyaksikan Alquran memakai bahasa dan lafal mereka, tetapi Alquran bukan puisi, prosa atau syair dan mereka tidak mempu membuat yang seperti itu (meniru Alquran).

Termasuk kesulitan seseorang, sebagaimana dikemukakan oleh (Al-Munawwar, 2002:33) ialah menundukkan seluruh kata dalam suatu bahasa, untuk setiap makna dan imajinasi yang digambarkannya. Sementara itu, Alquran tidak berbicara dengan sebuah kata kecuali 
sejalan dengan makna yang dikehendaki dan pada tingkat kedalaman paling tinggi.

Ketika merenungkan sebuah ayat yang menjelaskan cara menciptakan alam, misalnya dengan dasar sistem yang teratur dan peraturan yang tidak bertentangan satu dengan yang lain dan tidak rusak, maka ayat tersebut menjelaskan makna tersebut dengan fenomena gerak yang dapat dirasakan, yang berputar di depan kedua mata Anda sendiri, seakan-akan sedang berada di hadapan laboratorium dengan bergerak sangat cepat pada sistem yang berkelanjutan.

\section{KEMUKJIZATAN DARI SEGI PERISTIWA MASA LALU}

\section{Tentag Jasad Fir'aun yang Diselamatkan}

Kemukjizatan Alquran tentang peristiwa masa lalu, dapat ditemukan pada kemampuan Alquran mengungkap peristiwa masa lalu. Misalnya, peristiwa tenggelamnya Fir'aun. Alquran menyatakan bahwa tubuh Fir'aun diselamatkan dalam arti tidak hancur karena akan menjadi pelajaran bagi umat manusia. Allah swt. berfirman dalam Q.S Yûnus [10]:90-92 :

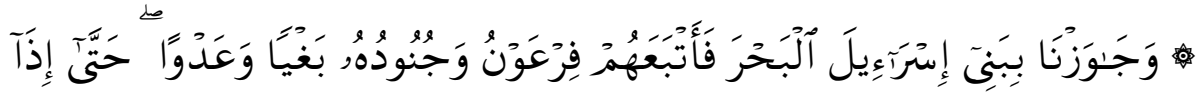

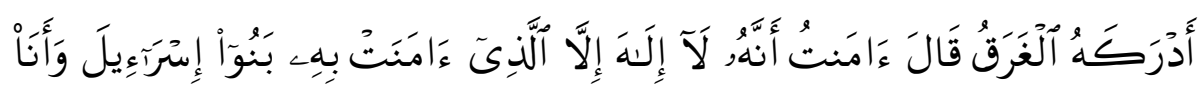

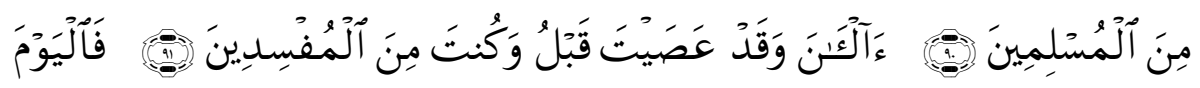

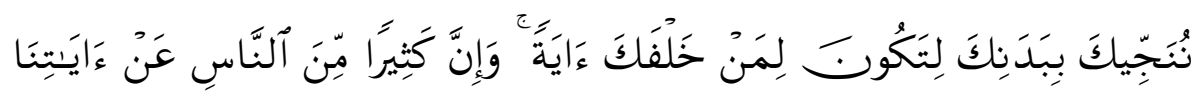

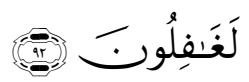

Terjemahnya :

Dan kami memungkinkan Bani Israil melintasi laut. Mereka pun diikuti oleh Fir'aun dan tentaranya, karena mereka hendak menganiaya dan menindas (Bani Israil). Ketika Fir'aun telah hampir tenggelam, berkatalah dia, "Saya percaya bahwa tidak 
ada tuhan melainkan Tuhan yang disembah oleh Bani Israil dan saya termasuk orang-orang yang berserah diri (kepada-Nya)." (Allah menyambut ucapan Fir'aun ini dengan berfirman), "Apakah sekarang (baru kamu percaya) padahal sesungguhnya kamu telah durhaka sejak dahulu dan hari ini Kami selamatkan badanmu, supaya kamu menjadi pelajaran bagi (generasi) yang akan datang sesudahmu dan sesungguhnya kebanyakan manusia lengah dari tanda-tanda kekuasaan Kami".

Farid (1987) menyatakan bahwa sangat menarik perhatian kita hanya Alquran dari semua kitab keagamaan dan buku-buku sejarah Bahkan terbukti kebenarannya setelah lewat dari 3000 tahun mayat Fir'aun ditemukan kembali. Tubuh Fir'aun ditemukan pada tanggal 6 Juli 1879 M. dan tersimpan dalam keadaan terpelihara di Mesium di Kairo.

\section{Tentang Kaum 'Âd dan Thâmûd serta Kehancuran Kota Iram}

Kaum 'Âd dan Thâmûd adalah kaum yang kepadanya diutus Nabi Saleh dan Nabi Hud. Kedua kaum ini dibinasakan oleh Allah swt. dengan gempa dan angin ribut yang sangat dingin lagi kencang. Peristiwa ini diabadikan dalam Q.S Al-Haqqah [69]:4-7, sebagai berikut:

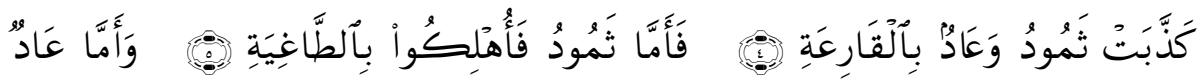

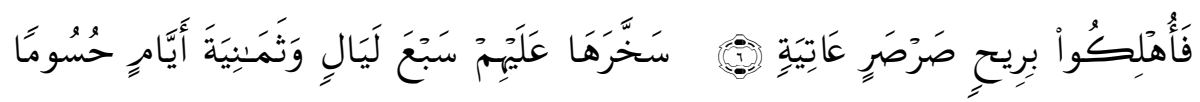

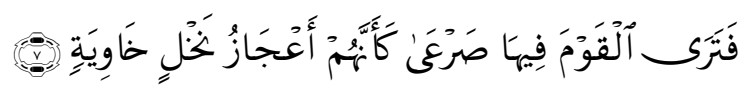

Terjemahnya:

Kaum Tsamud dan Ad telah mendustakan hari kiamat (4) Adapun Tsamud, maka mereka telah dibinasakan dengan kejadian luar biasa (petir dan suaranya yang menghancurkan) (5) sedangkan kaum Ad telah dibinasakan dengan angin yang sangat dingin lagi kencang (6) Allah menimpakan angin itu 
kepada mereka selama tujuh malam dan delapan hari secara terus-menerus, maka kamu melihat kaum Ad ketika itu, mati bergelimpangan bagaikan tunggul-tunggul pohon kurma yang telah kosong (lapuk) (7)

Di ayat lain, dikemukakan bahwa kaum 'Âd memiliki kemampuan yang luar biasa sehingga telah membangun kota Iram dengan tiang-tiang yang tinggi dan belum pernah dibangun di negeri lain sehebat dan seindah kota itu sebelumnya. Perhatikan informasi Q.S Al-Fajr [89]:6-9 berikut ini:

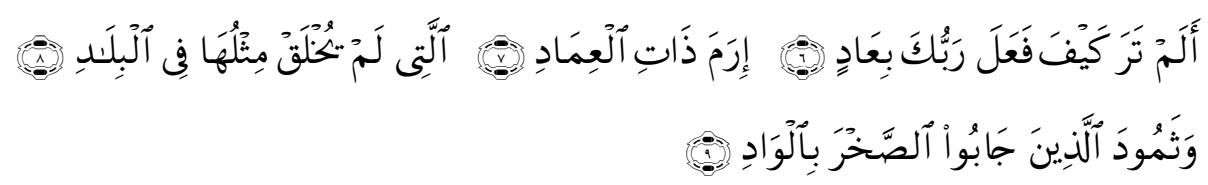

Terjemahnya:

Apakah kamu tidak memperhatikan bagaimana Tuhanmu berbuat terhadap kaum Ad (6) yaitu penduduk Iram yang mempunyai bagunan-bagunan yang tinggi (7) yang belum pernah dibangun (suatu kota) seperti itu, di negeri-negeri lain (8) dan kaum Tsamud yang memotong batu-batu besar di lembah (9).

Memperhatikan kedua ayat tersebut, persoalannya di manakah letak kemukjizatan Alquran ? Shihab (1997:198) mengemukakan bahwa pada tahun 1834 ditemukan di dalam tanah yang berlokasi di Hisn al-Guhrab dekat kota Aden di Yaman-sebuah naskah bertuliskan aksara Arab lama (Hymarite) yang menunjukkan nama Nabi Hud. Dalam naskah itu, menurut Shihab, antara lain tertulis, "Kami memerintah dengan menggunakan hukum Hud". Selanjutnya, pada tahun 1964-1969 dilakukan penggalian arkeologis, dan dari hasil analisis, pada tahun 1980 ditemukan infromasi dari salah satu lempeng tentang adanya kota yang disebut Samûtu, 'Âd dan Iram. Prof. Pattinato mengidentifikasikan nama-nama tersebut dengan nama-nama yang disebut pada surah Al-Fajr di atas.

Untuk memperkuat argumen tersebut, kembali mengutip Shihab (1997:198-199) bahwa bukti arkeologis lain tentang kota Iram adalah 
hasil ekspedisi Nicholas Clapp di Gurun Arabia Selatan pada tahun 1992. Kota Iram menurut riwayat adalah kota yang dibangun oleh Shaddad bin Ud, sebuah kota yang sangat indah dan ketika itu bernama Ubhur. Namun demikian, Tuhan mengubur kota itu dengan longsoran padang pasir sehingga menelan kota tersebut akibat kedurhakaan mereka.

\section{KEMUKZITAN ALQURAN PADA MASA YANG AKAN DATANG}

\section{Kemenangan Kerajaan Bizantiun terhadap Kerajaan Persia}

Di dalam Alquran, terdapat beberapa ayat yang menyatakan sesuatu yang akan terjadi pada masa yang akan datang. Di antaranya ialah ayat-ayat yang berbicara tentang kemenangan Kerajaan Bizantiun terhadap Kerajaan Persia, tentang kemenangan para sahabat Nabi Muhammad dalam perang Badar dan tentang masuknya nabi dan para pengikutnya ke dalam Masjidil Haram. Semua prediksi ini terbukti benar.

Tentang kemenangan Kerajaan Bizantiun terhadap Kerajaan Persia, dapat dilihat dalam Q.S Al-Rûm [30]:1-5:

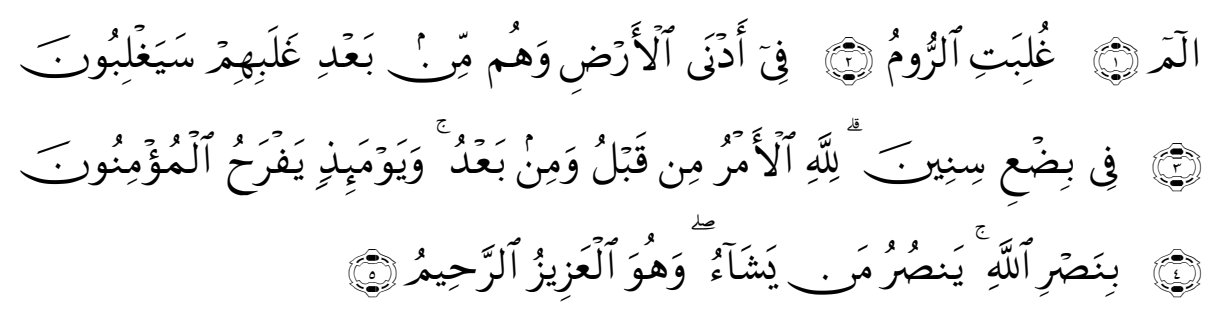

Terjemahnya :

Alif Lâm Mîm (1) telah dikalahkan bangsa Romawi (2) di negeri yang terdekat; dan mereka setelah dikalahkan itu akan menang (3) dalam beberapa tahun (antara tiga sampai sembilan tahun ). Bagi Allah ketetapan urusan sebelum dan sesudah (mereka menang), dan di hari (kemenangan) itu orang-orang Mukmin bergembira (4) karena pertolongan Allah. Allah menolong siapa yang dikehendaki-Nya. Dan Dia Mahaperkasa lagi Maha Penyayang (5). 
Prediksi Alquran yang dipandang sebagai kebenaran Alquran tentang peristiwa yang akan datang, dapat dilihat dari kemenangan kembali Kerajaan Romawi dalam pertempuran melawan Kerajaan Persia. Pada tahun 602 M. Kisra II sebagai Kaisar Kearjaan Persia, tidak lama sebelum Nabi Muhammad dilantik menjadi rasul, menyerang Kerajaan Romawi di mana laskar Romawi digilas habis oleh laskar Persia. Namun setelah itu, dunia Kristen bangkit membantu Romawi dan hanya dalam waktu sembilan tahun dari kekalahannya, Romawi berhasil kembali menghancurkan Kerajaan Persia, yang mana kemenangan mutlak Romawi tercapai pada tahun 627 M. Setelah Kisra II dibunuh oleh anak kandungknya sendiri. Ayat tersebut turun pada tahun $616 \mathrm{M}$. ketika Rasulullah berhijrah ke Madinah, yaitu 7 tahun setelah sudah ramalan Alquran (Farid, 1987: 768); Al-Munawwar, 2002:38).

\section{Tentang Kemenangan Umat Islam dalam Perang Badar}

Tentang kemenangan umat Islam dalam perang Badar, Alquran surah Al-Qamar [54]: 44-46 berikut :

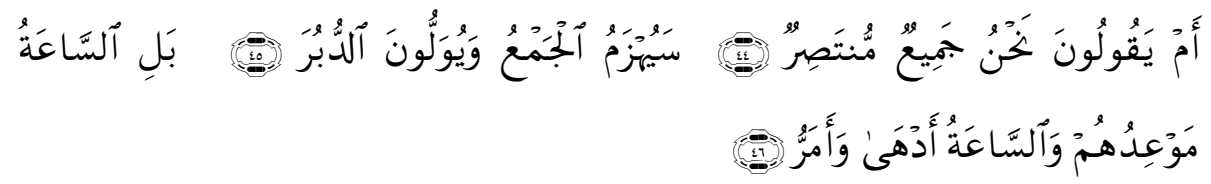

Terjemahnya:

Atau Apakah mereka mengatakan: "Kami adalah satu golongan yang bersatu yang pasti menang." Golongan itu pasti akan dikalahkan dan mereka akan mundur ke belakang.Sebenarnya hari kiamat Itulah hari yang dijanjikan kepada mereka dan kiamat itu lebih dahsyat dan lebih pahit.

Menurut Ibn 'Abbâs dalam Haytû (1989:16), ayat ini telah diwahyukan kepada Nabi Muhammad di Mekah tujuh tahun sebelum perang Badar terjadi . Pada masa turunnya wahyu, jumlah umat Islam sangat sedikit. Mereka diperlakukan secara kejam oleh kaum kafir. Mereka ditekan bukan saja dalam hal perekonomian, tetapi juga hal perlakuan pisik. Banyak di antara mereka yang dibaikot melakukan perdagangan; banyak pula yang diperlakukan secara kejam. Bahkan banyak yang dibunuh secara sadis. Memperhatikan situasi ini, Nabi mengatakan kepada kaum kafir: "Sungguh-sungguh, saya akan datang 
untuk membunuh kalian“. Selanjutnya, Allah mewahyukan kepada Muhammad ayat tersebut di atas, Ibn Abî $\mathrm{H} \square$ âtim memberikan informasi kepada kita bahwa 'Ikrima melaporkan bahwa ketika ayat tersebut diwahyukan, 'Umar berkata: "kelompok mana yang akan dikalahkan?" 'Umar selajutnya ketika perang Badar terjadi, saya melihat nabi mengenakan terompah sambil membaca ayat tersebut.

\section{Tentang Masuknya Nabi dan Para Sahabat ke Mekah}

Adapun tentang masuknya nabi dan para sahabat ke Mekah, Alquran surah Al-Fath [48]:27 menyebutkan:

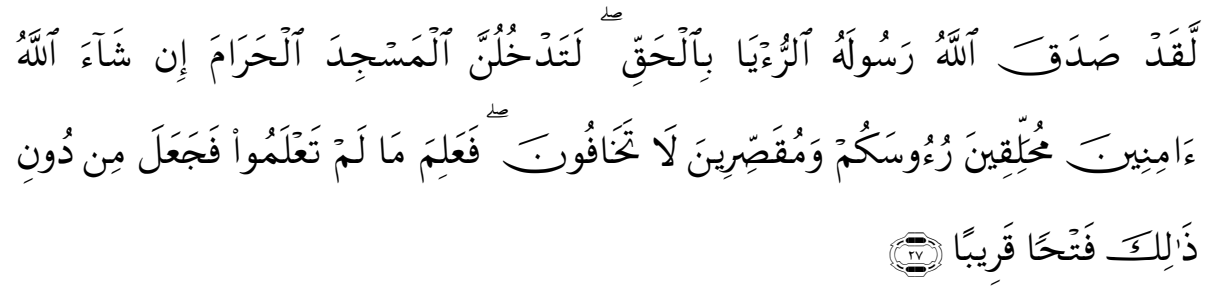

Terjemahnya:

Sesungguhnya Allah akan membuktikan kepada Rasul-Nya, tentang kebenaran mimpinya dengan sebenarnya (yaitu) bahwa Sesungguhnya kamu pasti akan memasuki Masjidil haram, insya Allah dalam Keadaan aman, dengan mencukur rambut kepala dan mengguntingnya, sedang kamu tidak merasa takut. Maka Allah mengetahui apa yang tiada kamu ketahui dan Dia memberikan sebelum itu kemenangan yang dekat.

Ayat ini menginformasikan bahwa sebelum nabi berangkat ke Medina untuk perjanjian Hudaibiyah pada pada tahun ke-6 Hijriah, ia telah bermimpi bahwa ia dan para sahabatnya, akan memasuki Mekah dengan aman. Ketika para sahabat mendengar hal ini, mereka sangat senang, dan percaya bahwa mereka akan mencapai Mekah pada tahun itu. Akan tetapi, ketika mereka kembali dari pembicaraan perdamaian Hudaibiyah antara nabi sebagai wakil dari kaum Muslimin, dan Suhayl ibn 'Amr sebagai wakil dari kaum Quraisy, pejanjian tersebut menjadikan beberapa orang dari kaum Muslimin tidak senang. Oleh karena itu, 'Umar mendatangi Abû Bakr dan yang lainnya untuk menanyakan alasan-alasan kesepakatan itu yang menurut dia, memuat persyaratan-persyaratan yang tidak disetujui oleh Islam dan kaum 
Muslimin (Al-T $\square$ abârî, 1977:180-182). Abû Bakr kemudian berkata kepada: "Apakah nabi memberitahukan kamu bahwa kamu akan memasuki Mekah tahun ini ? 'Umar menjawab, "Tidak". Abû Bakr menjawab, Sungguh, kamu akan memasuki Mekah dan akan melakukan tawaf di sana (Hawmad, 1986:500). Sekarang kita mengetahui bahwa bulan Zulkaidah tahun itu, mimpi nabi masuk ke Mekah akhirnya menjadi kenyataan (Al-Tabârî, 1977:636). Ketiga contoh kebenaran informasi Alquran tentang peristiwa yang akan terjadi pada masa yang akan datang, menunjukkan bahwa Alquran adalah wahyu dari Allah swt.

\section{PENUTUP}

Sebagai kesimpulan dari tulisan ini dapat dikemukakan bahwa Alquran adalah kitab suci yang benar-benar merupakan wahyu dari Allah swt. Hal ini dapat dilihat dari tantangan Alquran terhadap orangorang yang ingin menandingi struktur kebahasaan Alquran. Bahkan bukan saja dari aspek kebahasaan, Alquran juga sarat dengan informasi tentang peristiwa masa lampau, seperti jasad Fir'aun yang diselamatkan oleh Allah sebagai tanda kemukjizatan Alquran bagi umat manusia di sepanjang zaman; tentang keberadaan kota Iram yang terus-menerus dikaji dengan menggunakan pendekatan sains modern. Dan peristiwa yang akan terjadi pada masa yang akan datang seperti kemenangan kekaisaran Bizantiun atas kekaisaran Persia; tentang kemenangan umat Islam dalam perang Badar, dan tentang masuknya nabi ke Mekah setelah melakukan perjanjian Hudaibiyah, untuk melakukan fath al-Makkah.

\section{DAFTAR PUSTAKA}

Departemen Agama RI. 1982. Al-Qur'an dan Terjemahnya. Jakarta: Proyek Pengadaan Kitab Suci Al-Qur'an.

Farid, Malik Gulam. 1987. Al-Qur'an dengan Terjemahan dan Tafsir Singkat. Jakarta: Jemaat Ahmadiyah Indonesia.

Hawmad, As'ad Mahmûd. 1986. Aysar al-Tafâsîr. Cairo: Islamic Research Academy.

Haytû, Muhammad Hasan. 1989. Al-Mu'jizat al-Qur'âniyyah :Al-I'jâz al'Ilmî wa al-Ghaybî. Beirut : Mu'assasat al-Risâlah.

al-Himsî, Na'îm. 1952. Târîkh Fikrat I'jâz al-Qur'ân. Majallat al-Maj'ma' al-'Ilmî. (27): 240-241. 
Makhlûf, 'Abd. al-Ra'ûf. 1978. Al-Bâqillânî wa Kitâbuh I'jâz al-Qur'ân: Dirâsah Tahlîlîyah Naqdîyah.Beirut: Dâr Maktabat al-Hayâh.

al-Munawwar, Said Aqil Husin. 2002. Al-Qur'an Membangun Tradisi Kesalehan Hakiki. Cet. ke-2. Jakarta: Ciputat Press.

Shihab. M. Quraish, 1997. Mukjizat Al-Qur'an. Bandung: Mizan.

al-Tabârî, Muhammad ibn Jarîr. 1977. Tarîkh al-Rusul wa al-Mulûk. Jlid 2. Cairo: Dâr al-Ma'ârif.

al-Zidânî, Majî̀ bin Azîz, et al. 1997. Mu'jizat Al-Qur'an dan Assunnah tentang Iptek. Jakarta: Gema Insani Press. 